DOI: $10.19195 / 0137-1134.106 .26$

\author{
JAN MACIEJEWSKI \\ Uniwersytet Wrocławski \\ MAŁGORZATA STOCHMAL \\ Uniwersytet Wrocławski
}

\title{
SOCJOLOGICZNA ANALIZA PARTYCYPACJI PAŃSTWOWEJ STRAŻY POŻARNEJ W OCHRONIE LUDNOŚCI W STANACH NADZWYCZAJNYCH
}

\section{WSTĘP}

W artykule podjęto próbę przedstawienia zagadnienia dyspozycyjności podmiotów ulokowanych w systemie bezpieczeństwa publicznego państwa. Wskazano na dorobek socjologii grup dyspozycyjnych oraz znaczenie bezpieczeństwa jako istotnego zasobu społecznego. Specjalizacja podmiotów odpowiedzialnych za bezpieczeństwo jest następstwem urzeczywistniania się zagrożeń naturalnych, technogennych oraz społecznych o podłożu konfliktogennym. Ich specjalizacja zawodowa oraz działania oparte na logice dyspozycyjności, a więc natychmiastowej reakcji na zaistniałe zagrożenie, wpływa na przeciwdziałanie ich negatywnym skutkom. Zagadnienia owej dyspozycyjności przedstawia się z wykorzystaniem potencjału ratowniczo-gaśniczego Państwowej Straży Pożarnej. Bezpieczeństwo pozostaje więc dobrem wspólnym zapewnianym przez wyspecjalizowane podmioty i nie ma alternatywy tego typu instytucjonalizacji.

\section{RAMY ANALITYCZNE SOCJOLOGII GRUP DYSPOZYCYJNYCH}

Socjologia jako dyscyplina naukowa i konstruowana w niej „teoria socjologiczna jest narzędziem, za pomocą którego thumaczymy występowanie i dynamikę określonych struktur i procesów społecznych"'. Socjologia problematyzuje zagadnienia bezpieczeństwa i uogólnia te kwestie na użytek praktyki w zależności od kontekstu zrealizowanego programu badawczego. Taka socjologiczna refleksja

${ }^{1}$ K. Wysieńska, Z. Karpiński, Wprowadzenie, [w:] Procesy grupowe. Perspektywa socjologiczna, red. J. Heidtman, K. Wysieńska, Warszawa 2013, s. 11. 
jest niezbędna do zrozumienia oraz dalszego stanowienia porządku w przestrzeniach instytucjonalnych społeczeństwa, w tym rozwiązywania palących problemów wynikających ze wzrostu zagrożeń życia codziennego. Przedmiotem naukowej refleksji w dyscyplinie socjologii uczyniono sferę związaną z zapewnianiem bezpieczeństwa tworzonym i rozwijanym strukturom społecznym. Mamy tutaj na względzie socjologię grup dyspozycyjnych, która rozwijana jest we wrocławskim ośrodku uniwersyteckim.

Socjologia grup dyspozycyjnych ${ }^{2}$ jest wyspecjalizowaną dziedziną wiedzy, podejmującą analizy formacji, służb, inspekcji i straży odpowiedzialnych za stanowienie bezpieczeństwa i porządku publicznego w przestrzeni publicznej społeczeństwa. W miarę postępu cywilizacyjnego nastąpiło uprawomocnienie tych dyspozycyjnych podmiotów w systemach bezpieczeństwa państw narodowych.

Socjologia grup dyspozycyjnych jest podejściem teoretycznym określającym złożoność współczesnej rzeczywistości społecznej, wypracowała odmienny, zupełnie nowy schemat definiowania i postrzegania procesów i zjawisk zachodzących w systemach bezpieczeństwa, nie tylko militarnych, lecz także paramilitarnych i cywilnych. Dokonująca się cały czas instytucjonalizacja tej gałęzi wiedzy realizowana jest według następujących etapów: 1) samotny uczony; 2) nauka amatorska; 3) początki nauki akademickiej; 4) nauka ustabilizowana oraz 5) wielka nauka ${ }^{3}$. Rozwój socjologii grup dyspozycyjnych jest zaliczany do trzeciego, a nawet czwartego etapu jej instytucjonalnego rozwoju. Dokonania naukowe towarzyszące tej inspiracji badań socjologicznych nieustannie są rozwijane w obrębie Uniwersytetu Wrocławskiego. W socjologicznym ujęciu (re)definiowane są tożsamości podmiotów współuczestniczących w stanowieniu bezpieczeństwa i porządku publicznego.

Wskazana dyspozycyjność podmiotów zaangażowanych w systemy obronne i ochronne jest zjawiskiem emergentnym, a jednocześnie dążą one do redukcji negatywnych zjawisk i procesów wywołanych żywiołowością zagrożeń. Utworzenie tego typu wyspecjalizowanych i dyspozycyjnych formacji odpowiedzialnych za bezpieczeństwo i ochronę porządku publicznego jest efektem kształtowania kultury bezpieczeństwa, za którą stoi obawa ogółu społeczeństwa przed niebezpieczeństwami, którym należy przeciwdziałać w sposób zorganizowany i systemowy. Ponieważ stany nadzwyczajne grożą stabilności życia społecznego, formacje oparte na społecznej dyspozycyjności względem ochrony cenionych dóbr stają się istotnym czynnikiem wzmacniania potencjału państwa. Stanowią one niejako gwarancję odnawiania, stabilizowania i zabezpieczania struktur społecznych doświadczonych żywiołową siłą zagrożeń. Istnieje wysoka zależność między utworzeniem tego typu podmiotów w systemie bezpieczeństwa państwa a zachowywaniem bezpieczeństwa jego struktur.

2 J. Maciejewski, Grupy dyspozycyjne. Analiza socjologiczna, Wrocław 2014, s. 56.

${ }^{3}$ N. Kraśko, Instytucjonalizacja nauki w Polsce 1920-1970, Warszawa 1996, s. 14-16, za: E. Moczuk, Recenzja ksiażki Jana Maciejewskiego: Grupy dyspozycyjne. Analiza socjologiczna. Wydanie drugie poprawione, „Rzeszowskie Studia Socjologiczne” 2005, nr 5, s. 123-124. 
Formowanie się tych instytucji trwa wieki, ich tożsamości kształtują się nieprzerwanie aż do dzisiaj. Stają się one „podmiotami sprawczymi” w stanowieniu uwarunkowań bezpiecznej organizacji życia społecznego. W ciągu wieków eskalacja różnego rodzaju zagrożeń destabilizujących społeczeństwa przybierała zróżnicowane formy, dlatego też w warstwie organizacyjnej społeczeństwa dokonywała się specjalizacja podmiotów nie tylko autonomicznych w swoich obszarach działania, lecz także zależnych od siebie w dopełnianiu bezpieczeństwa systemowego.

\section{KULTUROWE DZIAŁANIA ZABEZPIECZENIA PRZED OGNIEM I INNYMI ZAGROŻENIAMI LOKALNYMI}

Organizacja praktyk przeciwdziałających pożarom w ujęciu historycznym, także z uwzględnieniem społecznych aspektów tej genezy, wskazuje, iż praktyki te stały się nieodłącznym elementem kształtowania bezpiecznego wspólnotowego życia ${ }^{4}$. Przekonanie to w dalszym ciągu wywiera znaczący wpływ na życie wspólnotowe i nadaje ton organizowaniu przestrzeni publicznych ${ }^{5}$. Fenomen pożarnictwa przeobraża się więc zgodnie ze zmianami cywilizacyjnymi, stojąc na straży interesu ogółu społeczeństwa, oferując wysokiej jakości usługi ratowniczo-gaśnicze, tak istotne $\mathrm{w}$ zakresie bezpieczeństwa wewnętrznego państwa.

Logika racjonalnego działania $\mathrm{w}$ obronie przed pożarami konstytuuje się z pewnością od początków wspólnotowego życia społecznego, jednak jej nowoczesną instytucjonalizację datuje się na trzecią ćwierć XVIII w. ${ }^{6} \mathrm{~W}$ przekazach historycznych odnajdujemy heroiczne działania na rzecz ochrony przed pożarami, co również zauważalne jest $\mathrm{w}$ obecnej walce $\mathrm{z}$ zagrożeniami. Są to oczywiście działania doniosłe dla danej wspólnoty. Osadzenie pożarnictwa w zinstytucjonalizowanym krajobrazie miejskim nastąpiło wraz z coraz silniejszym procesem rozróżniania między własnością prywatną a własnością publiczną.

\section{PROFESJONALNA OCHRONA PRZECIWPOŻAROWA}

Współcześnie ochrona przeciwpożarowa przestrzeni metropolitalnych w Polsce realizowana jest w głównej mierze przez zawodowe pożarnictwo. Państwowa Straż Pożarna pozostaje organem zajmującym się ochroną przeciwpożarową

${ }^{4}$ M. Stochmal, Państwowa Straż Pożarna w systemie bezpieczeństwa państwa. Studium socjologiczne, Wrocław 2015, s. 45-56.

5 R. Sennett, Upadek człowieka publicznego, Warszawa 2009.

${ }^{6}$ B. Hensler, Crucible of Fire: Nineteenth-century Urban Fires and the Making of the Modern Fire Service, Washington 2011, s. 172. 
oraz ochroną przed lokalnie występującymi zagrożeniami. Podstawowymi aktami prawnymi regulującymi działalność PSP są ustawy z dnia 24 sierpnia $1991 \mathrm{r}$. o Państwowej Straży Pożarnej ${ }^{7}$ oraz o ochronie przeciwpożarowej ${ }^{8}$. W zakres jej kompetencji wchodzą następujące działania:

1) rozpoznawanie zagrożeń pożarowych i innych miejscowych zagrożeń;

2) organizowanie i prowadzenie akcji ratowniczych w czasie pożarów, klęsk żywiołowych lub likwidacji miejscowych zagrożeń;

3) wykonywanie pomocniczych specjalistycznych czynności ratowniczych w czasie klęsk żywiołowych lub likwidacji miejscowych zagrożeń przez inne służby ratownicze;

4) kształcenie kadr na potrzeby Państwowej Straży Pożarnej i innych jednostek ochrony przeciwpożarowej oraz powszechnego systemu ochrony ludności;

5) nadzór nad przestrzeganiem przepisów przeciwpożarowych;

6) prowadzenie prac naukowo-badawczych w zakresie ochrony przeciwpożarowej oraz ochrony ludności;

7) współpraca z szefem Krajowego Centrum Informacji Kryminalnych w zakresie niezbędnym do realizacji jego zadań ustawowych;

8) współdziałanie ze strażami pożarnymi i służbami ratowniczymi innych państw oraz ich organizacjami międzynarodowymi na podstawie wiążących Rzeczpospolitą Polską umów międzynarodowych oraz odrębnych przepisów;

9) realizacja innych zadań wynikających z wiążących Rzeczpospolitą Polską umów międzynarodowych na zasadach i w zakresie w nich określonych ${ }^{9}$.

W celu ujednolicenia prowadzenia wymienionych działań powołano do istnienia krajowy system ratowniczo-gaśniczy (KSRG), którego organizację wspierają także akty wykonawcze ${ }^{10}$. Założeniem w konstruowaniu KSRG była potrzeba utworzenia jednorodnego środowiska organizacyjnego dla wszystkich podmiotów ratowniczych, aby maksymalizować ich efektywność. Zarządzanie tymi siłami ratowniczymi następuje na powiatowym, wojewódzkim i centralnym szczeblu administracji publicznej.

Zgodnie z właściwością terytorialną KSRG tworzony jest przez następujące organy władzy, które koordynują jego funkcjonowanie:

7 Tekst jedn. Dz.U. z 2009 r. Nr 12, poz. 68 z późn. zm.

8 Tekst jedn. Dz.U. z 2009 r. Nr 178, poz. 1380 z późn. zm. Wśród licznych aktów wykonawczych do tej bardzo często nowelizowanej ustawy należy przede wszystkim wymienić rozporządzenie Ministra Spraw Wewnętrznych i Administracji z 18 lutego 2011 r. w sprawie szczegółowych zasad organizacji systemu ratowniczo-gaśniczego.

9 Dz.U. z 2009 r. Nr 12, poz. 68 z późn. zm., art. 2.

10 Rozporządzenie Ministra Spraw Wewnętrznych i Administracji z dnia 18 lutego 2011 r. w sprawie szczegółowych zasad organizacji krajowego systemu ratowniczo-gaśniczego, Dz.U. z 2011 r. Nr 46, poz. 239 z późn. zm. 
— wójta (burmistrza lub prezydenta miasta),

- starostę,

- wojewodę ${ }^{11}$.

Przyjęte uregulowania prawne oraz ich aktualizacja umożliwiają utworzenie właściwych ram wykonywania powierzonych PSP zadań.

Formacje funkcjonujące w społecznej dyspozycyjności ${ }^{12}$ działają na zasadzie bezpośredniej interwencji, wymagającej organizacyjnego wydzielenia profesjonalnych grup realizujących usługi na rzecz bezpieczeństwa. Są to działania wykonywane w trudnych warunkach, w sytuacjach niestabilnych, niesprzyjających, których dynamika żywiołowości przekształca elementy antropotechnicznego ładu. Z pewnością znaczącą cechą ich służby jest poświęcenie na rzecz drugiego człowieka.

Są to specyficzne stany, które także zostały zdefiniowane w nomenklaturze prawnej. Odróżnienie ich statusu jest istotne w działalności formacji, służb, inspekcji i straży odpowiedzialnych za stanowienie bezpieczeństwa i porządku publicznego, działają one zgodnie z przypisanymi im uprawnieniami. Podmioty te jako grupy dyspozycyjne aktywnie współtworzą system bezpieczeństwa wewnętrznego kraju, który z kolei podlega zarządzaniu kryzysowemu w chwili wystąpienia sytuacji kryzysowej. Wyczerpującą definicję tych terminów przedstawił Karol Kiczka:

Zarządzanie kryzysowe to działalność organów administracji publicznej będąca elementem kierowania bezpieczeństwem narodowym, która polega na zapobieganiu sytuacjom kryzysowym, przygotowaniu do przejmowania nad nimi kontroli w drodze zaplanowanych działań, reagowaniu w przypadku wystąpienia sytuacji kryzysowych oraz na odtwarzaniu infrastruktury krytycznej lub przywróceniu jej pierwotnego charakteru. Z kolei przez sytuację kryzysową należy rozumieć sytuację będącą następstwem zagrożenia i prowadzącą w konsekwencji do zerwania lub znacznego naruszenia więzów społecznych przy równoczesnym poważnym zakłóceniu w funkcjonowaniu instytucji publicznych, jednak w takim stopniu, że użyte środki niezbędne do zapewnienia lub przywrócenia bezpieczeństwa nie uzasadniają wprowadzenia żadnego ze stanów nadzwyczajnych, o których mowa w art. 228 ust. 1 Konstytucji Rzeczypospolitej Polskiej ${ }^{13}$.

W takich sytuacyjnych uwarunkowaniach zachowanie ciągłej gotowości do zabezpieczania i ochrony struktur społecznych pozostaje ważnym zadaniem.

Uprawnienia nadane dyspozycyjnym formacjom są swego rodzaju zobowiązaniem władzy, ulokowanej na różnych szczeblach administracyjnych, do ochrony ważnych społecznie wartości, wyrażonym w formie umowy społecznej. Zobowiązanie do ochrony i obrony we współczesnym porządku społecznym ma status swoistego nawyku (habitus), który pozwala dostosować się do sytuacji wymagają-

11 B. Kogut, Krajowy System Ratowniczo-Gaśniczy. Aspekty prawne, [w:] Krajowy System Ratowniczo-Gaśniczy w latach 1995-2015. Postępy organizacyjno-prawne, logistyczne i taktyczno-ratownicze, red. J. Konieczny, M. Schroeder, Poznań 2015, s. 24.

12 J. Maciejewski, op. cit., s. 53.

${ }^{13}$ K. Kiczka, Administracja publiczna a bezpieczeństwo wewnętrzne, [w:] Bezpieczeństwo wewnętrzne w działaniach terenowej administracji publicznej, red. A. Chajbowicz, T. Kocowski, Wrocław 2009, s. 74-75. 
cych określonego typu działań. Habitualizacja działań ratowniczych legitymizuje władzę, ludzie widzą bowiem korzyść z jej uprawomocnienia się.

Owa habitualizacja — będąca etapem instytucjonalizacji — następuje w procesach wytwarzania wyspecjalizowanych wzorców działania w turbulentnych przestrzeniach społecznych, które z kolei w następstwie doskonalenia ich sformalizowanych struktur kształtują kolektywną tożsamość ${ }^{14}$.

Kształtowanie nawyków w zakresie działań ochronnych, obronnych i ratowniczych trwało dostatecznie długo, aby móc znaleźć odzwierciedlenie w praktyce życia codziennego.

Utworzone w sektorze publicznym grupy dyspozycyjne są swoistą manifestacją sprawności administracji terytorialnej, legitymując politykę w zakresie bezpieczeństwa zapewnianego na podległym terenie administracyjnym państwa. Formowanie się tego typu ładu zostało tak zinstytucjonalizowane, że zakres tych działań stał się standardem cywilizacyjnym współczesnych społeczeństw. W praktyce obywatele są świadomi kompetencji tych instytucji, ich funkcjonowanie jest powszechnie uznane, a działalność tych podmiotów realizuje oczekiwania względem tych ważnych usług publicznych. Porządek ten osadzony jest w kontekście prawnym, dlatego stabilizuje wspólnoty, nadając im zdolność do samoodtwarzania struktur społecznych w przypadku wystąpienia zagrożeń.

Sprawczość dyspozycyjnych formacji ratowniczych wzmacnia ład społeczny w zakresie bezpieczeństwa i stanowi istotny element organizacji współczesnych tożsamości państwowych, przysparzających korzyści społeczeństwom lokalnym. Usługi w sferze bezpieczeństwa publicznego są wyjątkowym mechanizmem kształtowania relacji społecznych, zabezpieczającym lub odtwarzającym istotne zasoby. Powszechnie rozumiane działania ratownicze urzeczywistniają doniosłość wartości życia i zdrowia, mienia i środowiska naturalnego, będących fundamentem wspólnotowej egzystencji.

\section{TOŻSAMOŚĆ PROFESJONALNEGO POŻARNICTWA}

Dynamika żywiołowych sił destrukcyjnych struktur społecznych ukształtowała współczesną strukturę systemu bezpieczeństwa państwa. Profesjonalne podmioty strzegące bezpieczeństwa realizują funkcje obronne, ratownicze i ochronne, które są racjonalnie wpisane w krajobraz społeczny wraz z nadanymi kompetencjami w stanowieniu bezpieczeństwa publicznego. Różnorodność tych profesji zawodowych wynika $\mathrm{z}$ wielości zagrożeń ujawnianych wraz z rozwojem cywilizacyjnym i postępem naukowym w strukturach rozwijających się społeczeństw. Zgodnie z koncepcją systemu społecznego Niklasa Luhmanna kształtowane oczekiwania w zakresie bezpieczeństwa projektują tożsamości owych podmiotów, któ-

14 M. Stochmal, op. cit., s. 131. 
re wykazują zdolność absorpcji ryzyka ${ }^{15}$. Służby, formacje i podmioty systemu bezpieczeństwa państwa zorientowane są na zabezpieczanie interesów zbiorowych przez troszczenie się o wspólnotowe wartości: zdrowie i życie, mienie i środowisko naturalne. Jest to bardzo ważna funkcja zabezpieczania środowiska społecznego i świadomość odpowiedzialności za te działania jest niezwykle wysoka.

Negatywne zdarzenia upośledzają tkankę społeczną, wywołując jej dysfunkcjonalność, a nawet niweczą dokonania ludzkości, uniemożliwiając przebieg procesów społecznych i wywołując negatywne następstwa w sferze społecznej, ekonomicznej, politycznej czy psychologicznej. Zdarzenia te są bardzo zróżnicowane: wypadki komunikacyjne, awarie techniczne, pożary, powodzie czy ataki terrorystyczne stanowią nieodłączną część naszego codziennego życia.

Wszystkie zdarzenia niekorzystne zakłócają rozwój lub trwanie jednostek, społeczności lokalnych czy też całych społeczeństw, a w skrajnych przypadkach wręcz uniemożliwiają im przetrwanie do momentu usunięcia zjawisk negatywnie na nią oddziałujących ${ }^{16}$.

Eliminacją tych negatywnych zjawisk zajmują się wyspecjalizowane formacje określane mianem grup dyspozycyjnych, ulokowanych w systemie bezpieczeństwa państwa.

Szczególny status dotyczy osób odpowiedzialnych za bezpieczeństwo publiczne, określonych w prawodawstwie jako funkcjonariusze. Stosunki publiczne funkcjonariuszy PSP formują się ze społecznością lokalną przez ich ciągłe zaangażowanie i gotowość do ochrony cenionych dóbr społecznych: zdrowia, życia, mienia oraz zasobów środowiska naturalnego. Potencjał, jaki jest wypracowywany $\mathrm{w}$ tej formacji, w znaczący sposób przyczynia się do umacniania bezpieczeństwa państwa. Formacje te pomagają w kształtowaniu przyjaznych warunków życia społecznego, co umożliwia społeczności jej dalszy wzrost.

Przejmowanie zadań w zakresie stabilizacji struktur społecznych przez profesjonalne podmioty przyczynia się do specjalizacji zawodowej tych podmiotów. W ramach pełnienia funkcji zawodowych funkcjonariusze PSP nie tylko korzystają ze zdobytej wiedzy i umiejętności, lecz także wkładają w wykonywanie obowiązków służbowych uczucia, angażując się emocjonalnie.

Zabezpieczanie przestrzeni publicznej przez profesjonalne podmioty oferujące usługi w zakresie bezpieczeństwa przyczynia się do stabilizacji struktur państwowych oraz ich wzrostu społecznego, ekonomicznego i cywilizacyjnego. Funkcjonariusze publiczni zajmujący się bezpieczeństwem są tak rozlokowani w strukturze społeczeństw lokalnych, aby przeciwdziałać zagrożeniom dokonującym często nagłego spustoszenia. Zniszczenia infrastruktury społeczeństw w wyniku żywiołowych sił generują znaczące nierówności społeczne, niejednokrotnie

15 N. Luhmann, Systemy spoleczne. Zarys ogólnej teorii, Kraków 2007, s. 293, 303.

16 J. Wolanin, Socjotechniczne aspekty prewencji, „Ochrona Przeciwpożarowa” 2005, nr 3 (13), s. 4 . 
ograniczające szanse na rozwój danego obszaru. Co więcej, skutki zagrożeń przyczyniają się do erozji przestrzeni publicznej przez umniejszanie spoistości struktur społecznych.

Jednocześnie mierzenie się z żywiołowością zagrożeń łączy się z odpowiednią reakcją na nie, co nierozerwalnie wiąże się z percepcją zagrożeń. Człowiek może subiektywnie ocenić aktualną sytuację na podstawie zdobytej wiedzy czy doświadczenia związanego z groźbą i w stosunku do tego konstruuje mechanizm poddawania się ujawnianym emocjom.

Zagrożenia to zjawiska wykraczające poza granice struktur społecznych, na przykład przybierając wymiar lokalny bądź nawet ponadnarodowy. Za opanowanie zagrożeń dręczących wspólnoty odpowiedzialne są wyspecjalizowane formacje, służby, inspekcje, straże i inne podmioty mające status prawny wykonywania działań dotyczących bezpieczeństwa państwa. Z racji uprawnień oraz umiejętności do działań w środowisku (nie)bezpieczeństwa te dyspozycyjne podmioty realizują profesjonalne usługi na rzecz członków wspólnot lokalnych.

Dyspozycyjność w sferze bezpieczeństwa należy zdefiniować jako swoistą właściwość podmiotów z zakresu bezpieczeństwa, które są w pełni gotowe do niesienia pomocy w sytuacji zagrożenia cenionych przez społeczeństwo wartości. Podstawową logiką kształtującą dyspozycyjność jest

zabezpieczanie rozmaitych obszarów życia zbiorowego, które są mniej czy bardziej podatne na wszelkiego rodzaju zagrożenia. Głównym przejawem ich dyspozycyjności jest funkcja, jaką pełnią w przeciwdziałaniu i zwalczaniu skutków zagrożeń ekologicznych, cywilizacyjnych i społecznych, które mogłyby destabilizować życie danej społeczności lub społeczeństwa ${ }^{17}$.

Dyspozycyjność pozostaje racjonalnym mechanizmem organizacji działań w sektorze bezpieczeństwa, wskazując jednocześnie na zdolności do zabezpieczania struktur społecznych.

Zobowiązanie do pełnej gotowości w przeciwdziałaniu negatywnym siłom zagrożeń pozostaje istotne dla trwałości ładu społecznego. Chodzi bowiem o takie spersonalizowanie obszaru aktywności zadaniowej poszczególnych formacji systemu bezpieczeństwa, aby posiadane przez nich uprawnienia umożliwiały efektywną walkę z zagrożeniami. Dzięki owej dyspozycyjności zaspokajają oni najbardziej podstawowe potrzeby społeczeństwa w zakresie bezpieczeństwa.

Każde zagrożenie niesie znaczące przekształcenia w strukturze społecznej i w konsekwencji umniejsza spoistość stosunków międzyludzkich, także wywołując szkody w jej infrastrukturze. W miarę rozwoju cywilizacyjnego dąży się więc do ukształtowania racjonalnych procedur działania na wypadek doświadczania żywiołowości zagrożeń. Procedury te pozwalają na skuteczne redukowanie destrukcyjnych zagrożeń środkami dysponowanymi przez dany podmiot systemu bezpieczeństwa. Wśród środków wpływających na osiąganie przewagi nad siłami

17 J. Maciejewski, op. cit., s. 55. 
zagrożeń należy wymienić specjalistyczną wiedzę — zgodnie z podejściem A. Abbotta $\mathrm{w}$ zawodach profesjonalnych ta specjalistyczna wiedza stanowi ich kapitał społeczny wypracowywany w praktyce ${ }^{18}$. Specjalizacja każdej profesji w zakresie bezpieczeństwa pozostaje więc naturalnym atrybutem prowadzącym do współzależności tych podmiotów w stanowieniu bezpieczeństwa, oferują one bowiem usługi komplementarne względem siebie. Te wyspecjalizowane formy współpracy mają zasadnicze znaczenie dla (re)konstrukcji ładu społecznego, gdyż ich zadaniem jest dążenie do przejmowania kontroli nad swoim otoczeniem.

Wyłaniające się z podziału pracy profesje oparte są na etosie służby. Przez skuteczność swych zawodowych działań dążą do panowania nad zagrożeniami ujawniającymi się w danym krajobrazie przestrzeni społecznej, co czynią za pomocą legitymacji zdobytej wiedzy. Dominacja ta zawiera w sobie dążność do całkowitej kontroli nad zjawiskami i procesami zagrożeń będących w ich obszarze kompetencyjnym, dlatego też działania te nie prowadzą do rywalizacji między podmiotami funkcjonującymi w środowisku (nie)bezpieczeństwa. Realizacja tych profesji wiąże się z codziennym doświadczaniem totalnych sił zagrożeń, których skutki mogą być nieprzewidywalne. Aspekty tego nieuchronnego i totalnego uniwersum przeciwstawiane są zinstytucjonalizowanym i wystandaryzowanym procedurom działania, ujętym w systemowych rygorach. Okoliczność ta znacząco utrudnia walkę z zagrożeniami, angażując siły i środki umożliwiające odparcie ich destruktywnych sił oraz zażegnanie negatywnych oddziaływań na struktury społeczne. Zagrożenia ekologiczne, technogenne i społeczne o podłożu konfliktogennym pozostają siłą możliwą do zredukowania, ale za pomocą zorganizowanych i dyspozycyjnych działań wyspecjalizowanych służb bezpieczeństwa, które mają znaczący kapitał społeczny i adekwatne wyposażenie sprzętowe, przeszkolenie oraz doświadczenie w tego typu działaniach.

Wymaga to jednak zorganizowanych interakcji ukierunkowanych na kontrole żywiołowych sił zagrożeń, których przybywa wraz z rozwojem cywilizacyjnym i postępem naukowym. Takie działania wynikają z konieczności ciągłego przystosowywania się do uwarunkowań sytuacyjnych, a adaptacja ta powinna być realizowana $\mathrm{z}$ uwzględnieniem zdobytej w praktyce wiedzy. Tak wypracowywana zdolność do zabezpieczania i obrony w sferze bezpieczeństwa konstruuje zawody wysokiego ryzyka, których wykonywanie wiąże się z ciągłym narażaniem na oddziaływanie czynników stresowych, zagrażających zdrowiu i życiu.

Osoby wykonujące tego typu zawody muszą mieć wysokie predyspozycje do radzenia sobie z sytuacjami stresogennymi oraz emocjami, jakie ujawniają się w takich sytuacjach. Przedstawiciele zawodów w sferze bezpieczeństwa realizują bowiem działania związane z ochroną zdrowia, życia, mienia czy środowiska naturalnego. Motywy realizacji tych działań zawodowych są szczytne, jednak

18 A. Abbott, The System of Professions. An Essay on the Division of Expert Labour, Chicago 1998, s. 86. 
wiążą się także z doznawaniem emocji negatywnych, wywołanych urzeczywistnieniem się niekorzystnych zdarzeń. Osoby takie przyjmują postawę altruistyczną i podejmują takież działania, mając na względzie cudze dobro ${ }^{19}$. Realizowane poświęcenie na rzecz osób drugich polega więc na bezinteresownym, ale profesjonalnym udzieleniu im pomocy w sytuacji zagrożenia.

Zainteresowania naukowe zagadnieniem stresu są domeną nauk społecznych i humanistycznych, głównie psychologii, dążących nie tylko do opisu tego zjawiska, lecz także do określenia mechanizmów jego kształtowania się w określonych warunkach. Uchwycenie mechanizmów tego specyficznego stanu psychicznego pozwala ludziom radzić sobie z sytuacjami stresogennymi. Należy jednak pamiętać, iż dany stan psychiczny wywołują konkretne zdarzenia, fakty czy działania i oddziałują na postawę człowieka.

Zagadnieniem stresu interesuje się także socjologia, która dąży do określenia uwarunkowań społecznych stwarzających sytuacje stresogenne dla danego człowieka. Jako zjawisko stres definiuje się jako stan wzmożonego napięcia nerwowego, będący reakcją uczuciową na oddziaływanie negatywnych bodźców fizycznych lub psychicznych. Może on prowadzić do mobilizacji sił organizmu do poradzenia sobie ze stresorami bądź też doprowadzić do różnego rodzaju zaburzeń. Sytuacje stresogenne mogą być w pełni zrozumiałe, tylko wtedy gdy odniesione zostaną do kontekstu społecznego, w którym dane jednostki podlegające stresowi się znajdują. Zauważa się tu ścisłą współzależność interakcji uczestnictwa, na przykład funkcjonariusza $\mathrm{w}$ działaniach ratowniczo-gaśniczych i zagrożenia, na jakie jest narażony przy ratowaniu cenionych wartości. We współczesnej przestrzeni metropolitalnej funkcjonuje wiele grup dyspozycyjnych składających się na zewnętrzny i wewnętrzny system bezpieczeństwa narodowego. Służą one do osiągnięcia celów, jakie wyznaczyło sobie państwo w sferze społecznej, ekonomicznej i politycznej. Szczególnym zadaniem państwa jest utrzymanie zorganizowanego potencjału i kapitału, w tym infrastruktury społeczeństwa, w stanie niezdegradowanym, umożliwiającym jego sprawne funkcjonowanie. Troska ta szczególnie przyświeca od początków rewolucji przemysłowej, od kiedy gwałtownie rozwijający się przemysł ujawnił wiele zagrożeń życia społecznego. Dochodzą do tego też zagrożenia ekologiczne oraz społeczne, leżące u podstaw konfliktów międzyludzkich. Dlatego żyjąc w zbiorowościach, dążymy do względnego spokoju będącego przejawem bezpieczeństwa.

Wyodrębnione subsystemy bezpieczeństwa mają swoistą specyfikę wynikającą z zakresu kompetencyjnego oraz zadań stawianych poszczególnym podmiotom. Znacząco różnią się one między sobą między innymi rodzajem ustrukturyzowania swoich elementów według określonych schematów. Tak wyraźnie odznaczająca się funkcjonalistyczna perspektywa analizy życia zbiorowego wyjaśnia nam za-

19 M. Ossowska, Motywy postępowania. Z zagadnień psychologii moralności, Warszawa 2002, s. 169. 
leżności między elementami tych systemów. W takim właśnie oglądzie ukazuje się nam Państwowa Straż Pożarna jako podsystem w całościowym systemie bezpieczeństwa państwa.

Państwowa Straż Pożarna funkcjonuje w wewnętrznym systemie bezpieczeństwa naszego kraju, współtworząc i koordynując jednocześnie KSRG oraz tworząc zintegrowaną jego formę. Oceniając kompetencje w zakresie bezpieczeństwa, dostrzec należy specyfikę PSP na tle innych grup dyspozycyjnych systemów zarówno paramilitarnych, jak i niemilitarnych, współtworzących wewnętrzny system bezpieczeństwa. Uświadomienie tego łączyć się musi z określeniem ich współodpowiedzialności za system bezpieczeństwa, w którym funkcjonują i który współtworzą.

Istnienie i działanie służb ratowniczych w społeczeństwie przeciwstawione jest licznym zagrożeniom ekologicznym, cywilizacyjnym i społecznym. Dlatego też działania PSP w systemie bezpieczeństwa ukierunkowane są na wyeliminowanie zjawisk i procesów niebezpiecznych dla życia społecznego. Świadomość zagrożeń kształtuje ciągły rozwój tej kategorii zawodowej, zwiększając szansę na dalszy rozwój cywilizacyjny, a więc niczym niezakłócony rozwój człowieka. Dlatego też „niebezpieczeństwo” jest wartościowane negatywnie, natomiast powszechnym dążeniem jest osiągnięcie „,bezpieczeństwa”, które w każdym wymiarze życia społecznego będzie postrzegane pozytywnie.

Przez dziesięciolecia strażacy wypracowali sobie wysokie uznanie społeczeństwa przez aktywny udział w przywracaniu bezpieczeństwa społeczności lokalnych. Nie jest ważne, czy jest to pożar, powódź, huragan, wypadki drogowe czy zagrożenia ze strony rojów lub gniazd owadów błonkoskrzydłych (pszczoły, osy) — funkcjonariusze PSP zawsze profesjonalnie likwidują powstałe zagrożenia.

Uzmysławiając sobie zagrożenia cywilizacyjne, musimy wskazać na procesy fizyczne i chemiczne będące skutkiem wszelkiego rodzaju awarii — komunikacyjnych, technicznych czy też chemicznych. Nasuwa się tutaj wniosek, iż kryzys spowodowany eliminacją człowieka z procesów pracy przez technikę przyczynił się do jego ponownego zaangażowania w sferze bezpieczeństwa przy ochronie ośrodków przemysłowych i miejskich, przed awariami maszyn i urządzeń. Postępujący proces globalizacji zwiększa niepewność pod względem częstotliwości występowania zagrożeń mających dla człowieka niszczący potencjał.

\section{PODSUMOWANIE}

PSP jako grupa dyspozycyjna stanowi w socjologicznym rozumieniu instytucję i wspólnotę. Członków tej grupy łączy więź przynależności do tej samej kategorii zawodowej, a różnicują przyjęte role zawodowe, które dookreślają funkcje i pozycje społeczne wynikające z tej przynależności. Codzienna praktyka społeczna potwierdza jej ważność, żaden z mieszkańców nie jest bowiem przygotowany 
do tego, aby skutecznie walczyć z pożarami i innymi miejscowymi zagrożeniami, do których to zadań są przeznaczeni profesjonalnie przygotowywani funkcjonariusze PSP. Poza tym nie zawsze obywatel jest w stanie sam podjąć takie działania, bez współpracy z innymi osobami, bez posiadania specjalistycznej wiedzy o specyfice zagrożenia oraz bez odpowiedniego wyposażenia w specjalistyczny sprzęt. Możemy zadać przypadkowym osobom pytanie: czy potrafisz udzielić pierwszej pomocy, chcąc uratować życie drugiej osoby? Doświadczenie pokazuje, że niewiele osób to potrafi, a przeważająca liczba $\mathrm{z}$ nich wręcz obawia się podejmowania takich działan. Ten prosty przykład ukazuje nam, jak niekorzystne byłyby następstwa braku formacji ratowniczej, jaką jest Państwowa Straż Pożarna.

\title{
SOCIOLOGICAL ANALYSIS OF THE PARTICIPATION \\ OF THE STATE FIRE SERVICE IN CIVIL PROTECTION DURING EXTRAORDINARY MEASURES
}

\begin{abstract}
Summary
The article has a theoretical character - it is based mainly on the presentation of sociology of dispositional groups. The text represents the complexity of the system of state security and the role of actors involved in providing safety. Academic considerations are placed in a sociological orientation enabling a uniform explanation of phenomena related to the state of emergency. The essence of social dispositional groups is presented on the example of The State Fire Service.
\end{abstract}

